Short Note

\title{
Intercalated Duct Cells in the Moorhen (Gallinula chloropus) Pancreatic Islet
}

\author{
By \\ Ken-ichiro MUTOH, Hidekazu WAKURI and Kazumi TANIGUCHI \\ Department of Veterinary Anatomy, School of Veterinary Medicine and Animal Sciences, Kitasato University, \\ Towada-shi, Aomori, 034-8628 Japan
}

- Received for Publication, September 2, 1998 -

Key Words: Intercalated duct, Moorhen, Pancreatic islet, Stellate shape

\begin{abstract}
Summary: Intercalated duct cells are present in the alpha and beta islets of the moorhen pancreas. The intercalated duct cells adhere to each other via intercellular junctional complexes on the apical side, projecting many microvilli into the lumen. They also extend slender cytoplasmic processes between islet endocrine cells. These intercalated duct cells appear to have a stellate shape, and to wrap their cytoplasm around the endocrine cells. These observations suggest that intercalated ducts not only pass through the islets, but also play a role in support to islet cells.
\end{abstract}

While excretory ductules surrounded by several endocrine cells have been observed in the islets of elasmobranchs (Thomas, 1940) and snakes (Thomas, 1942), little information is available on ductules in the avian pancreatic islets. There have been many reports on the relationship between the exocrine and endocrine pancreas, both ontogenetically and phylogenically. They have described islet cells within exocrine pancreatic ducts, and sometimes having a common lumen with tubules in the early development in anuran (Ortiz et al., 1991), avian (Ono, 1967), rats (Fujii, 1979), bovine (Sanchez, 1987), and human embryos (Like and Orci, 1972). Intercalated ducts and centroacinar cells have been reported to be mingled with islet cells in some cases of inflammation, cancer, or hyperactivation of the pancreas (Yang and Hunter, 1959), Wang et al. (1995) have described proliferation and differentiation of exocrine duct cells as representing the major mechanism of endocrine beta-cell neogenesis in the rat after pancreatic duct ligation.

Intercalated ducts in the exocrine pancreas have been reported to penetrate through the islets in the normal chicken (Mutoh et al., 1997), however, it remains unknown whether intercalated ducts penetrate the islets only in the chicken or in other fowl as well. The present study describes the ultrastructural characteristics of the intercalated ducts in the pancreatic islets of the moorhen (Gallinula chloropus).

\section{Materials and Methods}

A farmer rescued a female moorhen (body weight $275 \mathrm{~g}$ ) from attack by a stray cat, but it was in critical condition and died on the way to the veterinary hospital. The farmer gave the dead moorhen to veterinary student, and the student brought it to our laboratory. The cause of death was fractures of the cervical vertebrae. Each lobe of the pancreas was removed immediately, cut into thin slices (about $1 \mathrm{~mm}$ thick), and fixed in $1.5 \%$ glutaraldehyde and $0.5 \%$ paraformaldehyde in $0.1 \mathrm{M}$ phosphate buffer at $\mathrm{pH} 7.4$, and then in $1 \%$ osmium tetroxide in the same buffer. The slices were dehydrated in a graded series of ethanol, and embedded in epoxy resin. Ultrathin sections were cut with a Reichert ultra-microtome, stained with uranyl acetate and lead citrate, and examined with a Hitachi H-7000 electron microscope.

\section{Results and Discussion}

Two types of islets were observed in the moorhen pancreas, alpha islets and beta islets. The alpha cells were columnar in shape, had relatively 
less developed cellular organelles, including a sparse granular endoplasmic reticulum, few free ribosomes, small, rounded mitochondria, bundles of fine filaments, and a slightly developed Golgi apparatus (Figs. 1,2). The characteristic alpha dense granules were surrounded by a membrane about $500 \mu \mathrm{m}$ in diameter. The beta cells were round, oval, or irregular in shape, and contained more or less developed cell organelles and characteristic beta granules. The granules were polymorphic and consisted of three main types: acicular or bar-shape, annular, and spherical, and they were enclosed by a smooth membrane about $400 \mu \mathrm{m}$ in diameter. Delta cells were observed in both islets, and were characterized by the presence of less dense spherical granules having a diameter of about $500 \mu \mathrm{m}$ (Figs. $3,4)$, the same as the normal chicken pancreas (Mikami and Mutoh, 1971).

The intercalated ducts were observed in the periphery and/or near the center of the pancreatic islets. These ducts connected the exocrine acinar portion with the peripheral portion of the islets by a narrow lumen and consisted of several epithelial cells. The epithelial cells were stellate in shape, connected to each other by intercellular junctional complexes apically, and had many microvilli and a few cilia on their luminal side. The nuclei of these cells were relatively small, round, oval or polygonal, and were usually situated on the apical side of the cytoplasm, the same as the normal chicken pancreas (Mutoh et al., 1997). Schwann cells or Cajal's interstitial cells are known to be present in the pancreatic islets in stellate form (Ushiki and Ide, 1988). However, these cells were not Schwann cells or Cajal's interstitial cells, because they formed ducts with lumina, had microvilli on their luminal margins, and they formed junctional intercellular complexes with each other, sometimes reaching the basement membrane, without any attached nerve elements. The slender cytoplasmic processes of these cells extended abluminally, between the endocrine cells. They frequently surrounded the endocrine cells and reached the basement membrane. These cells contained small mitochondria, small Golgi apparatus, sparse granular endoplasmic reticulum, microtubules, microfibrils, and a few lysosomes, but no endocrine granules (Figs. 1-4). These findings it is suggest that the intercalated ducts of the pancreas not only penetrate through the islets, but serve some function to islet endocrine cells.

By contrast, the mixture of stellate cells and endocrine cells in the adenohypophysis is generally recognized as folliculo-stellate cells and/or marginal cells. Despite very different embryonic origins, the intercalated duct cells in the pancreatic islets re- semble folliculo-stellate cells in their association with endocrine cells. The folliculo-stellate cells constituted the follicular margin, and have slender cytoplasmic projections extending between granular cells in a number of species (Kobayashi, 1975; Leatherland and Percy, 1976; Shiotani, 1980; Harrison et al., 1982; Kameda, 1991). Several papers have suggested that folliculo-stellate cells may be involved in phagocytosis, support, contraction, stem cell function, and paracrine regulation of hormone secretion. Mutoh et al. (1998) found that intercalated duct cells darkened and increased lysosomes in number and size in the cytoplasm after tolbutamide treatment, as they support to endocrine islet cells. The intercalated duct cells of the pancreas which penetrate through the islets, may perform functions similar to those of folliculo-stellate cells in relation to islet endocrine cells.

\section{Acknowledgments}

The authors wish to thank Miss Y. Yonezawa for her valuable assistance during the course of this research.

\section{References}

1) Fujii $S$. Development of pancreatic endocrine cells in the rat fetus. Arch Histol Jpn 1979; 42:467-479.

2) Harrison $F$, Van Hoof $J$ and Vakaet $L$. The relationship between the folliculo-stellate network and the thyrotropic cells of the avian adenohypophysis. Cell Tissue Res 1982; 226:97-111.

3) Kameda Y. Occurrence of colloid- containing follicles in the pars distalis of pituitary glands from aging guinea pigs. Cell Tissue Res 1991; 263:115-124.

4) Kobayashi Y. Follicle formation by marginal cells in the mouse anterior pituitary. J Electron Microsc (Tokyo) 1975; 24:41-42.

5) Leatherland JF and Percy R. Structure of the nongranulated cells in the hypophysial rostral pars distalis of cyclostomes and actinopterygians. Cell Tissue Res 1976; 166:185-200.

6) Like AA and Orci L. Embryogenesis of the human pancreatic islets: A light and electron microscopic study. Diabetes 1972; 21:511-534.

7) Mikami S and Mutoh K Light and electron-microscopic studies of the pancreatic islet cells in the chicken under normal and experimental conditions. Z Zellforsch 1971; 116:206-227.

8) Mutoh K, Wakuri H, Liu B and Taniguchi K. Intercalated duct cells in the chicken pancreatic islet. Okajimas Folia Anat Jpn 1997; 74:147-154.

9) Mutoh K, Wakuri H, Liu B, Seno $M$ and Taniguchi $K$ Electron microscopic study of intercalated duct cells in the chicken pancreatic islet and effects of tolbutamide administration. Okajimas Folia Anat Jpn 1998; 75:(in print).

10) Ono $K$. The cytogenesis of the alpha and beta islets in the chicken pancreas. Acta Anat Nippon 1967; 42:123-131. (in Japanese) 
11) Ortiz de Zarate A, Villaro AC, Etayo JC, Diaz de Rada O, Montuenga LM, Sesma P and Vazquez JJ. Development of the endocrine pancreas during larval phases of Rana temporaria. An immunocytochemical and ultrastructural study. Cell Tissue Res 1991; 264:139-150.

12) Sanchez A and von Lawzewitsch I. Histological study of endocrine pancreas; cell differentiation process in Langerhans's islets of bovine fetus and adult bovine. Communicaciones Biologicas 1987; 5:345-365.

13) Shiotani Y. An electron microscopic study on stellate cells in the rabbit adenohypophysis under various endocrine conditions. Cell Tissue Res 1980; 213:237-246.

14) Thomas TB. Islet tissue in the pancreas of the elasmo- branchii. Anat Rec 1940; 76:1-13.

15) Thomas TB. The pancreas of snakes. Anat Rec 1942; 82:327-345.

16) Ushiki T and Ide C. Autonomic nerve networks in the rat exocrine pancreas as revealed by scanning and transmission electron microscopy. Arch Histol Cytol 1988; 51:71-81.

17) Yang $\mathrm{YH}$ and Hunter WC. The relation of the pancreatic ducts to the islets of Langerhans. Arch Pathol 1959; 67:505-514.

18) Wang RN, Kloppel G and Bouwens L. Duct-to islet-cell differentiation and islet growth in the pancreas of duct-ligated adult rats. Diabetologia 1995; 38:1405-1411. 


\section{Explanation of Figures}

Plate I

Fig. 1. Electron micrograph of a portion of an alpha islet from the moorhen pancreas showing the organization of the intercalated duct (ID) and endocrine cells. $\times 5,000$. A, alpha cell; $D$, delta cell; arrowhead, intercellular junctional complex; arrow, portion of the ID cell process extending to the basement membrane.

Fig. 2. Electron micrograph of a portion of an alpha islet from the moorhen pancreas showing the organization of the intercalated duct (ID) and endocrine cells. (The lumen portion is a higher magnification of part of Fig. 1). $\times 10,000$. A, alpha cell; arrowhead, intercellular junctional complex; asterisk, lumen of the ID. 


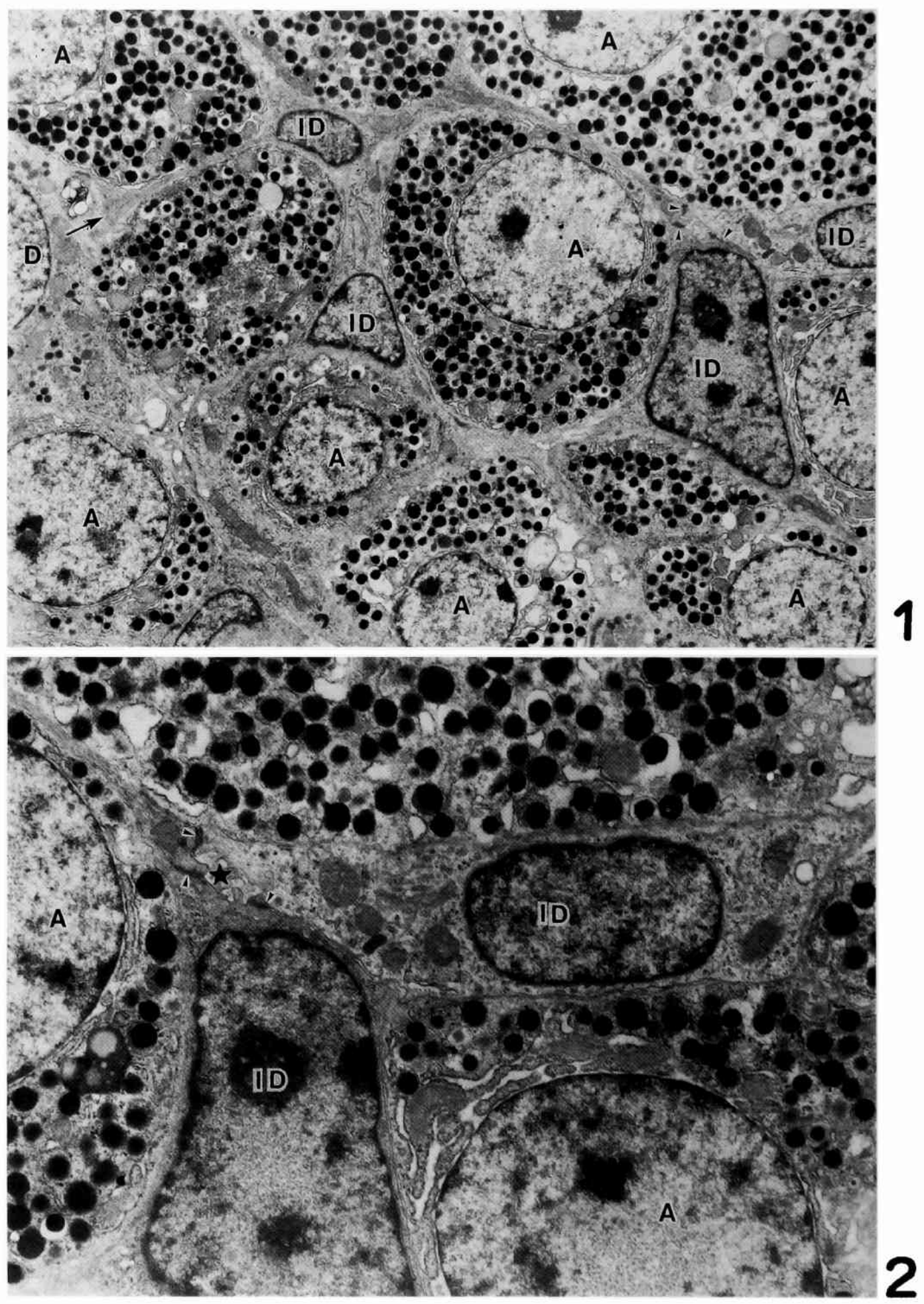




\section{Plate II}

Fig. 3. Electron micrograph of a portion of a beta islet from the moorhen pancreas showing the organization of the intercalated duct (ID) and endocrine cells. $\times 5,000$. B, beta cell; arrowhead, intercellular junctional complex; asterisk, lumen of the ID. arrow, portion of the ID cell process extending to the basement membrane.

Fig. 4. Electron micrograph of a portion of a beta islet from the moorhen pancreas showing the organization of the intercalated duct (ID) and endocrine cells. $\times 10,000$. B, beta cell; arrowhead, intercellular junctional complex; asterisk, lumen of the ID; double arrowhead, cilia. 

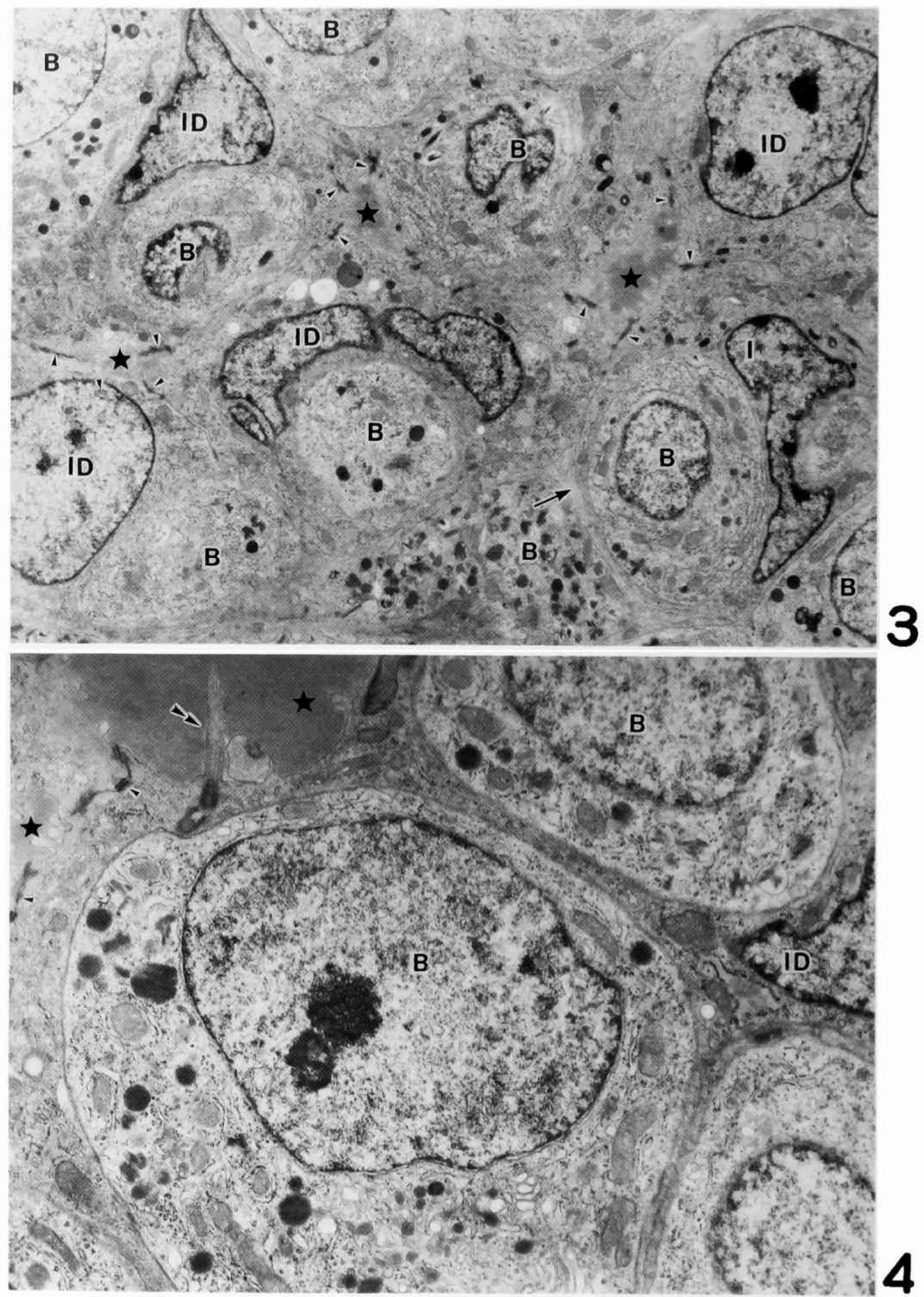